\title{
Estudio de la técnica de limpieza de la caliza limosa dolomitizada del Mioceno de Tarragona alterada en ambiente urbano
}

\section{Technique for cleaning Tarragona Miocene age dolomitized silty limestone, altered by urban pollution}

\author{
M. Iglesias $^{(*)}$, J. L. Prada(*) y N. Guasch(*)
}

Recepción/Received: 10-V-07

Aceptación/Accepted: 20-I-08

publicado online/Online publishing: 14-II-08

\section{RESUMEN}

En este trabajo se exponen los estudios realizados para valorar la técnica de limpieza más apropiada de la calcisiltita muy dolomitizada del Mioceno medio (Serravalliense) de Tarragona empleada en la Iglesia del Convento de Les Saleses (Barcelona), material pétreo muy empleado en el modernismo catalán para la talla de elementos decorativos y escultóricos.

El material, al igual que en la mayoría de los edificios modernistas donde se ha utilizado, presentaba degradación importante con costras negras muy reactivas, sales solubles y arenizaciones. Además del origen ambiental de las patologías, éstas también estaban relacionadas con la pátina original de tratamiento, cristalina e hidrófuga, aplicada en toda su superficie.

Tras el análisis del material pétreo, de la pátina, y de las alteraciones, que hicieron descartar los métodos de limpieza basados en agua y los químicos en forma de apósito; se estudió si una limpieza con abrasivos a baja presión y el empleo puntual de láser podían ofrecer un resultado adecuado. Se comprobó su efectividad y se determinaron los parámetros para ambas técnicas.

Palabras clave: limpieza, proyección de abrasivos, láser, restauración, arquitectura.

\section{SUMMARY}

This report sets out the studies carried out in order to assess the most appropriate cleaning technique for the very dolomitized calcisiltite from the middle Miocene (Serravallian) from Tarragona, used in The Church of Les Saleses Convent (Barcelona). This stone was frequently used in Catalan Modernista buildings for the carving of decorative and sculptural details.

As in the majority of the Modernista buildings where it was used, this material showed signs of considerable degradation, with highly reactive black crusts, a high percentage of soluble salts and sanding. As well as being of atmospheric origin, the pathologies were also linked to the original crystalline and water repellent protective patina treatment applied to the entire building surface.

Following the analysis of the stonework, patina and alterations, the use of cleaning methods based on water and on chemicals in poultice form had to be rejected. The feasibility of cleaning with abrasives at low pressure and the use of laser at specific points was studied. The positive results determined the parameters used for both techniques.

Keywords: cleaning, abrasive blasting, laser, restoration, architecture.

(*) CETEC-patrimoni. Universitat Autònoma de Barcelona / Institut Químic de Sarrià. (Barcelona, España). 


\section{INTRODUCCIÓN}

Los trabajos de limpieza en un edificio histórico son de vital importancia para su mantenimiento y conservación, ya que suponen una intervención irreversible. El análisis de los materiales, de sus tratamientos, y de sus alteraciones, es el que determinará, principalmente, la técnica concreta a emplear. Estos primeros resultados permitirán descartar, a priori, algunas de las técnicas posibles, centrando el estudio en las más apropiadas; teniendo presente que no existe un único método de limpieza y que, por tanto, pueden ser necesarios diferentes procedimientos en una misma intervención.

Los ensayos previos de limpieza en obra y en laboratorio realizados por el restaurador, y su posterior análisis, determinarán las ventajas e inconvenientes de las técnicas; y permitirán establecer los parámetros aproximados a emplear durante los trabajos, con la finalidad de afectar lo mínimo posible a los materiales.

En este caso, el estudio se centró en el Convento de Les Saleses (Barcelona, 1882-85), obra de Joan Martorell. El conjunto fue concebido como un convento de clausura para las religiosas de esta congregación aunque, desde hace décadas, es un centro docente de los Maristas. Se desarrolla siguiendo el perímetro del solar, ocupando una superficie, en planta, de unos $3000 \mathrm{~m}^{2}$.

La parte más destacada es la Iglesia (Figura 1). Su entrada principal está en el Paseo de Sant Joan no 90, una de las vías principales del Eixample derecho de la ciudad, al lado de la avenida Diagonal, en calles abiertas al tráfico y con un gran volumen de circulación (1). El edificio está a unos 3500 metros de la línea de la costa, y cercano a

\section{INTRODUCTION}

In historic buildings, cleaning is of vital importance for maintenance and conservation, since the effects of unsuitable methods are irreversible. The specific technique to be used is primarily based on an analysis of materials, treatments and alterations. The results of preliminary tests suffice to disregard certain techniques a priori and focus the study on the most appropriate processes. Moreover, as there is no single cleaning method, several different procedures may be required in any given operation.

Preliminary field and laboratory tests conducted by the restorer and subsequent analysis of the results determine the advantages and drawbacks of the various techniques, while establishing the approximate working parameters to minimize their effects on the materials.

In this case, the study focused on Les Saleses (Salesian) Convent at Barcelona (1882-85), planned by Joan Martorell. Initially designed to be a cloistered convent for the nuns of that congregation, the compound has for many decades housed a school run by the Marists. The limits of the buildings, whose perimeter follows the lot boundaries, cover an area of around $3000 \mathrm{~m}^{2}$.

The most prominent structure is the church (Figure 1). Its main entrance stands at 90 Paseo de Sant Joan, one of the main thoroughfares on the right-hand side of the "Eixample" or nineteenth expansion of the Medieval city, alongside Diagonal Avenue in an area with heavy vehicle traffic (1). The building is sited about 3500 metres from

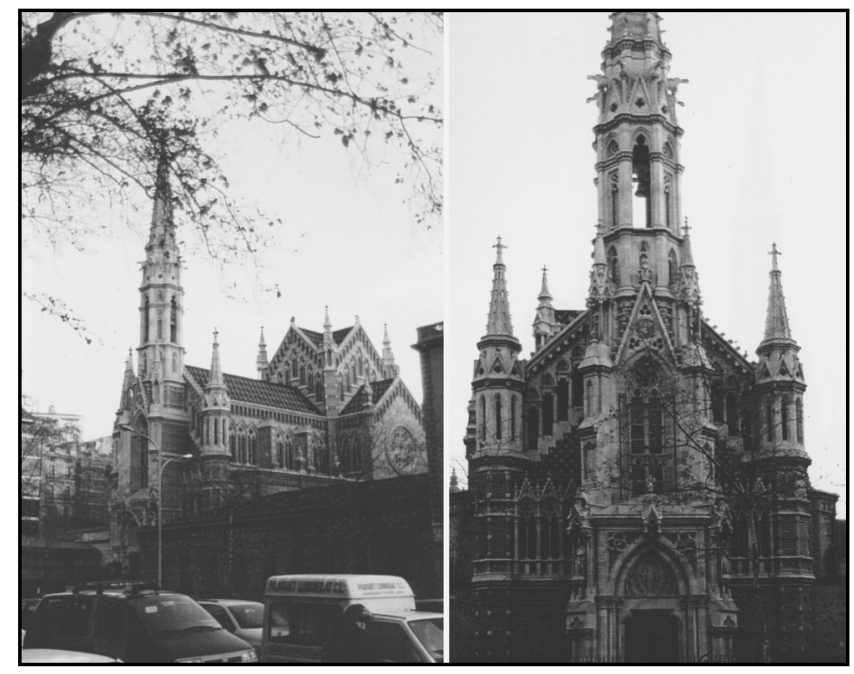

Figura 1. Iglesia del Convento de Las Salesas: vista general y fachada principal. Figure 1. Church of the Convent of Les Saleses: general view and main façade. 
antiguas zonas industriales de la ciudad, actualmente desaparecidas.

La concepción formal de la Iglesia tiene influencia evidente del gótico centroeuropeo y del gótico mudéjar, empleándose para su construcción una gran variedad de materiales (caliza, arenisca, mármol, ladrillo, cerámica vidriada, estuco pintado, etc.), que proporcionan un aspecto polícromo a todo el edificio (2).

De todos los materiales empleados en la Iglesia, el estudio se centró en la caliza y en su pátina, por ser los más alterados y presentar mayor problemática en su tratamiento. Ambos se utilizaron en la fachada y en los múltiples elementos decorativos del resto del edificio, lo que representa una superficie aproximada de $1200 \mathrm{~m}^{2}$.

El edificio no ha tenido intervención de limpieza documentada a lo largo de su historia; y ya, en imágenes de mitad del siglo XX, se aprecia un grado de ensuciamiento y alteración muy elevado que ha ido en aumento hasta la actualidad.

\section{MATERIALES Y MÉTODOS}

Se partió del estudio del material (caliza y pátina) y de sus alteraciones para, con los datos obtenidos, evaluar qué limpiezas podrían ser más adecuadas, siguiendo la secuencia lógica de intervención en restauración de monumentos según recomendaciones existentes en este campo $(3,4)$.

Primero, se realizaron diversas inspecciones visuales en la obra para obtener los datos iniciales sobre los materiales y su estado de conservación. Así mismo, se tomaron diferentes muestras de piezas que se iban a sustituir en los trabajos, para su análisis y para la realización de los ensayos de limpieza. El muestreo fue directo con extracción de fragmentos o escamas de piedra, pátina y costras.

Para el estudio de los materiales y alteraciones se realizaron láminas delgadas que se observaron a lupa estereoscópica y microscopio óptico petrográfico. Posteriormente, mediante microscopio electrónico de barrido (SEM) se completó el análisis de su textura petrográfica y su composición. En el examen de los componentes dolomíticos de la piedra y en el de la pátina se realizaron tinciones selectivas de la calcita sobre lámina delgada (5). En el estudio de las sales solubles de las zonas más afectadas se realizó una campaña de aplicación de apósitos de los que se analizaron sus extractos acuosos, midiendo su conductividad e identificando y cuantificando los aniones por cromatografía tipo HPLC.

Para la evaluación de la limpieza, todos los ensayos realizados se observaron tanto en muestra directa sin embuti- the coastline and near what was once an industrial area of the city.

Central European Gothic and "Mudéjar" Gothic influences are clearly visible in the general form of the church, while the polychrome effect is achieved by the wide variety of materials (limestone, sandstone, marble, brick, glazed ceramics, painted stucco and so on) used in its construction (2).

Of all these materials, the present study focused on the most severely altered and most difficult to treat, the limestone and its coating. Coated limestone was used on the façade and many of the decorative elements on the rest of the building, together totalling an area of approximately $1200 \mathrm{~m}^{2}$.

There is no record of stone cleaning operations at any time in the history of the building and the severe soiling and alteration already visible in mid-twentieth century photographs have worsened in the interim.

\section{MATERIALS AND METHODS}

A preliminary study of the material (limestone and coating) and its alterations was conducted and the data obtained were used to determine the most suitable type of cleaning, following existing recommendations on the sequence of operations in monument restoration $(3,4)$.

First, several field inspections were carried out to obtain the initial data on the materials and their state of conservation. Samples of the pieces that were to be replaced were also taken for analysis and cleaning trials. Direct sampling methods were deployed, taking fragments or scaled pieces of stone, coating and crust.

Thin sections of the materials and alterations were studied under a stereomicroscope and a petrographic optical microscope. The petrographic texture and composition were analyzed with scanning electron microscopy (SEM). The thin sections were selectively stained for calcite to identify dolomitic components in the stone and coating (5). After poultices were applied to the areas most severely affected by soluble salts, their aqueous extracts were analyzed for conductivity, using HPLC (high performance liquid chromatography) to identify and quantify the anions.

Cleaning was evaluated by conducting trials both on the raw samples and the thin sections and observing the 
ción como en lámina delgada, con las mismas técnicas ópticas utilizadas en el estudio de los materiales, y a partir de los primeros datos así obtenidos, se completó su análisis mediante SEM y microscopía óptica láser confocal.

En el estudio mediante SEM de los materiales, las alteraciones y los ensayos de limpieza, las muestras se metalizaron con carbono y se trabajó con voltajes de 15 y 20 kV, en algún caso se bajó a 12 kV; y se utilizó la ventana EDX en modo fino para detectar mejor los elementos ligeros. Se emplearon tanto electrones secundarios (SEI) como retrodispersados (BSEI). En el estudio de los ensayos de limpieza con microscopio óptico láser confocal, las muestras de los fragmentos de piedra se colocaron en una mordaza de vidrio específica del portamuestras del microscopio para su análisis.

Los equipos utilizados en la investigación han sido la lupa estereoscópica Leica MZFLIII con objetivos 0,63, 1 y 2x, fluorescencia en 4 canales, luz polarizada y cámara digital DC250; el microscopio óptico petrográfico y metalográfico Zeiss Jenapol-U; el microscopio electrónico de barrido (SEM JEOL JSM-6300), equipado con un espectrómetro de dispersión de energías tipo EDX Link Isis-200, con una resolución de 138 eV (boro-uranio); y el microscopio óptico láser confocal Leica TCS SP2 AOBS con resolución de $0,2 \mu \mathrm{m}$, láser de diodo (405 nm), $\operatorname{Ar}(458,476,488$, y 514 $\mathrm{nm})$ y He-Ne (561 y $633 \mathrm{~nm}$ )

\subsection{Estudios previos}

\section{Material pétreo}

Se trata de una caliza del Mioceno medio (Serravalliense), de la provincia de Tarragona, cuyas canteras están a 90 $\mathrm{km}$ al sur de la ciudad de Barcelona. La roca está formada mayoritariamente por micrita (calcita inferior a $4 \mu \mathrm{m}$ ) en una proporción de un $50-60 \%$ y cristales de dolomita polifásica (de entre 30 y $50 \mu \mathrm{m}$ ) en una proporción del $40 \%$. Tiene también, componentes detríticos, mayoritariamente silíceos, con proporciones muy variables aunque siempre inferiores al $10 \%$. Es de color naranja pálido (very pale orange - 10 YR 8/2) (6). En concreto, se trata de una calcisiltita muy dolomitizada (7-9), de la que se analizaron diferentes muestras para comprobar datos de investigaciones anteriores $(10,11)$; destacando, preferentemente para el caso que nos ocupa, su predisposición a la alteración de origen diagenético al sufrir sus cristales de dolomita una disolución diferencial de sus núcleos.

En esta construcción se usaron dos variedades, que proceden de la misma cantera, con presencia de exoesqueletos (Figura 2); en una de tamaño centimétrico, de 2 a 12 $\mathrm{cm}$, y en la otra de tamaño milimétrico, de 2 a $6 \mathrm{~mm}$. Estas dos variedades litológicas se deben a cambios late- results with the same optical techniques as used to study the materials. These initial data were supplemented with SEM and confocal laser optical microscopy.

In the SEM studies of the materials, alterations and cleaning trials, the samples were metallicized with carbon at working voltages of 15 and $20 \mathrm{kV}$, lowered in some cases to $12 \mathrm{kV}$. The EDX window was set to high resolution to better detect light elements. Both secondary (SEI) and backscattered (BSEI) electron imaging were used. In the confocal laser optical microscipic study of the cleaning trials, the samples taken from the stone fragments were placed in a glass clamp specifically designed for the microscope sample holder.

The devices used for the research included a Leica MZFLIII stereomicroscope with $x 0.63, x 1$ and $x 2$ lenses, four-channel fluorescence, polarized light and a DC250 digital camera; a Zeiss Jenapol-U petrographic and metaIlographic optical microscope; a JEOL JSM-6300 scanning electron microscope, fitted with a boron-uranium EDX Link Isis-200 energy dispersive spectrometer with a resolution of $138 \mathrm{eV}$; and a Leica TCS SP2 AOBS confocal laser optical microscope with a resolution of $0.2 \mu \mathrm{m}$ and diode (405 nm), $\operatorname{Ar}(458,476,488$ and $514 \mathrm{~nm})$ and He$\mathrm{Ne}(561$ and $633 \mathrm{~nm})$ lasers.

\subsection{Preliminary studies}

\section{Stone material}

The stone studied is a middle Miocene (Serravallian) limestone from the province of Tarragona, quarried 90 $\mathrm{km}$ south of the city of Barcelona. The rock consists of $50-60 \%$ micrite (calcite smaller than $4 \mu \mathrm{m}$ ) and $40 \%$ multi-phase dolomite crystals (from 30 to $50 \mu \mathrm{m}$ ). It also has variable proportions, but always under $10 \%$, of primarily siliceous detritic compounds. Its colour is very pale orange (10 YR 8/2) (6). More specifically, it is a highly dolomitized calcisiltite (7-9), different samples of which were analyzed to verify data from previous studies $(10,11)$. The finding most relevant to the present survey was its proneness to alteration of diagenetic origin, since the nuclei of its dolomite crystals undergo differential dissolution.

The two varieties used on this building, both from the same quarry, had exoskeletons (Figure 2), although a full order of magnitude larger in one (from 2 to $12 \mathrm{~cm}$ ) than in the other (from 2 to $6 \mathrm{~mm}$ ). These two stone varieties are the outcome of lateral changes in the facies. Porosity 
rales de las facies. En ambas, la porosidad es de carácter intergranular (predominante) e intragranular. La porosidad total de la roca en cantera, estudiada en investigaciones anteriores mediante porosimetría de mercurio (10), está entre un 25-30\%, con predominio de la microporosidad (radio de acceso al poro inferior a 7,5 $\mu \mathrm{m}$ ), y el volumen de porosidad atrapante es muy elevado, superando el $60 \%$, por la mala comunicación de la red porosa.

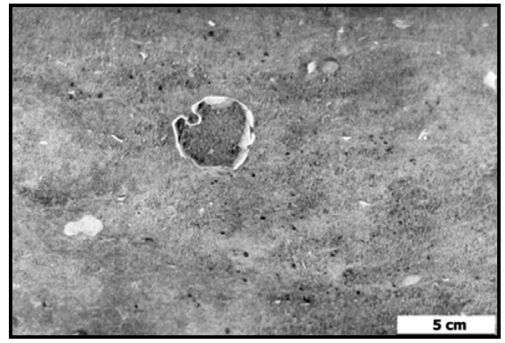

Figura 2. Imagen "in situ" de un sillar con exoesqueletos de tamaño centimétrico.

Figure 2. "In situ" image of an ashlar with exoskeletons of centimetric size.

La litología con exoesqueletos de medida centimétrica se usó para toda la sillería del cuerpo del campanario, cimborrio y ábside; mientras que la litología con exoesqueletos de tamaño milimétrico, variedad muy utilizada en el modernismo catalán para hacer elementos escultóricos por su facilidad de labra, se destinó a todos los elementos ornamentales del edificio, las esculturas exentas y la figuración del tímpano de la puerta principal.

\section{Pátina de tratamiento}

Toda la superficie de esta caliza, así como su mortero de juntas, estuvo recubierta por una pátina (Figura 3). Ésta, se supone aplicada por los constructores ya que, en la historia del edificio no ha habido ninguna intervención, en exterior, con montaje de andamio hasta el punto más alto del campanario donde se conserva la pátina (60 metros) que pudiera apuntar a una aplicación posterior al momento de su construcción. Además, en edificios de la misma época donde se usó este material pétreo, aparece un tratamiento similar. Este sería el caso de edificios como el Hospital de la Santa Creu i Sant Pau y la Casa de les Punxes, entre otros; así como, en algunas viviendas del Eixample que tienen elementos decorativos en esta caliza.

En la Iglesia de les Saleses, la pátina aparece, visualmente, como una capa endurecida de aspecto cristalino y color ocre-siena, similar a una pasta de mortero muy pobre en árido, con diferencias de grosor en su aplicación, comprobando, al mojarla, que presenta un carácter hidrófugo. was observed to be (predominantly) intergranular and intragranular in both. The total porosity of the quarry stone, determined in previous studies via mercury porosimetry (10), ranged from 25 to 30\%, with microporosity (pore access radius under $7.5 \mu \mathrm{m}$ ) prevailing. The closed porosity volume was high, over $60 \%$, due to low network interconnectivity.

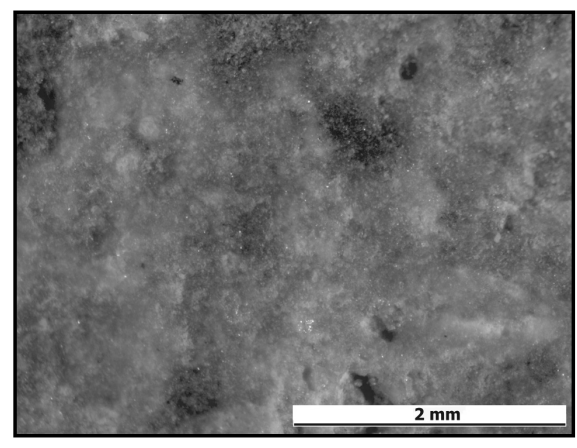

Figura 3. Imagen a lupa estereoscópica de la superficie de la pátina.

Figure 3. Stereoscopic magnifying glass image of the patina surface.

The stone variety with centimetre-scale exoskeletons was used for the ashlars throughout the belfry, dome and apse, while the stone with millimetre-scale exoskeletons, a variety that can be readily carved and therefore popular among Catalonian modernist architects, was employed in all the ornamental elements on the building, including the free-standing sculptures and the decorative figures on the tympanum over the main entrance.

\section{Treatment coating}

The entire surface of this limestone, along with the mortar in the masonry joints, was coated (Figure 3). This coating, found even at the top of the belfry (60 metres), is assumed to have been applied by the builders, for at no time in its history subsequent to construction has the building undergone works on the exteriors requiring the scaffolding that would have been needed to apply the coating at such heights. Furthermore, similar treatments can be found on other buildings made of this stone and erected in the same period. Examples include the Hospital de la Santa Creu $i$ Sant Pau and Casa de les Punxes, as well as a number of residential buildings in the "Eixample" whose decorative elements are sculpted in this limestone.

In Les Saleses Church, this coating is a hardened, ochresienna crystalline layer of variable thickness, similar to a mortar paste with a low dry matter content. When wetted, it proved to be water-repellent. 
Su observación al microscopio óptico petrográfico, muestra un comportamiento óptico diferenciado del de la piedra, debido a su composición mineral y su fino tamaño microcristalino, que genera un oscurecimiento y una tonalidad grisácea de la misma, observada a luz paralela.

En la observación a SEM, mediante imagen de secundarios y retrodispersados, se pone de manifiesto su textura microcristalina, ya detectada por técnicas ópticas, y también, pequeñas fisuras que podrían corresponder a retracciones durante el secado o por dilatación térmica. Igualmente, se pudieron confirmar las diferencias de grosor de la pátina que, en las muestras analizadas, oscilaba entre 170 y $500 \mu \mathrm{m}$. Los análisis SEM-XEDS y el mapa de elementos determinan una capa compuesta por calcio, azufre, silicio, aluminio, magnesio y hierro (Figura 4).
Under the petrographic microscope, it could be distinguished from the stone due to its mineral composition and the small size of its microcrystals, which afforded it a darker, greyish hue visible under parallel light.

SEM observation with secondary and backscattered imaging confirmed the microcrystalline texture detected with optical techniques and revealed the presence of tiny cracks that may have appeared during drying or as a result of thermal expansion. This technique also identified differences in coating thickness which, in the samples analyzed, ranged from 170 to $500 \mu \mathrm{m}$. The SEM-XEDS analyses and the element map showed that the layer contained calcium, sulphur, silicon, aluminium, magnesium and iron (Figure 4).

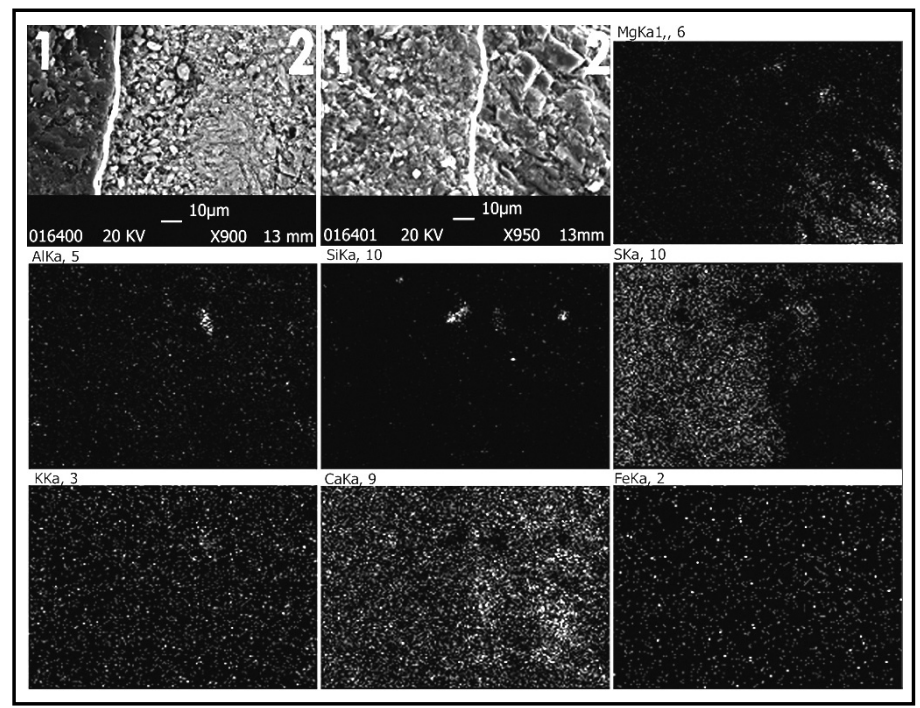

Figura 4. Imagen SEM-XEDS. Mapa de composición elemental: pátina (1) piedra (2).

Figure 4. SEM-XEDS image: elemental composition map: patina (1) stone (2).

Se trata de una pátina de yeso con escasos áridos o cargas. Su dureza es superior a la que presentan, habitualmente, pátinas con esta composición, lo que parece apuntar la posibilidad del empleo de algún aditivo endurecedor de naturaleza no determinada. Esto, unido a su carácter hidrófugo, indica un tratamiento conservativo generalizado para evitar los problemas que el agua ocasiona en esta roca. Su coloración ocre-siena es uniforme en toda la superficie. No se aprecian variaciones de color en función de su ubicación en el edificio y, los ligeros cambios observados, se deben a las diferencias de grosor en su aplicación.

\section{Alteraciones y estado de conservación}

Estos materiales presentan un mal estado de conservación. Las formas de alteración más fácilmente visibles son la costra negra y los diferentes depósitos superficiales de
It was, in fact, a plaster with a very high water/solid ratio. As it proved to be harder than usual for coatings with such a composition, a hardener of an indeterminate nature may possibly have been added. This, along with its water repellence, indicates that the treatment was intended to protect the stone against water-induced damage. Its ochre-sienna colour was observed to be uniform throughout. Indeed, stone position in the building did not determine colour variations, and the slight changes in hue found were due to differences in thickness.

\section{Alterations and state of conservation}

The materials were in a poor state of repair. The most readily visible types of alteration were black crust, surface dirt and bird droppings, along with gaps in the coating. 
suciedad y de excrementos de aves, así como la pérdida de pátina. Existen además, alteraciones que suponen pérdidas de volumen, como desplacaciones y arenizaciones asociadas a eflorescencias salinas, que afectan tanto a la caliza como a su pátina.

La pérdida de pátina original se presenta de forma diferente en el edificio. En el campanario, en las torres laterales de fachada y en los coronamientos del cimborrio está totalmente desaparecida; conservándose, únicamente, en molduras decoradas que tienen una función de cornisa. Su ausencia está relacionada con la erosión eólica y el lixiviado, al tratarse de zonas desprotegidas por tener mayor altura que los edificios que las rodean. El material pétreo que se observa en ausencia de la pátina presenta ligeras arenizaciones y retrocesos superficiales.

En cambio, en los cuerpos inferiores de edificio, hasta unos 18 metros de altura del nivel del suelo, se conserva de forma muy irregular. En toda esta superficie se observan ampollas y descamaciones de la pátina hasta su separación total del sustrato (Figura 5), que dejan un material arenizado, con eflorescencias y subeflorescencias visibles. Su separación y su pérdida están asociadas a la percolación del agua y a las sales solubles.
Alterations involving dimensional loss were also observed, such as flaking and the disaggregation associated with salt efflorescence, affecting both the limestone and the coating.

The original coating was observed to have worn differently on different parts of the building. On the belfry, towers flanking the façade and dome pinnacle it had disappeared entirely, with traces found only on the decorative mouldings that serve as cornices. Indeed, with a higher elevation than the surrounding buildings, these areas have been more exposed than the rest to wind erosion and leaching. In the absence of the protection afforded by the coating, the stone was found to be slightly disaggregated and honeycombed.

On the lower parts of the building, in turn, up to around 18 metres above grade, the cover was found to be highly irregular. Blistering, scaling and detachment were observed throughout (Figure 5), while the bared limestone showed disaggregation, efflorescence and sub-efflorescence. Coating detachment was associated with water seepage and soluble salts.

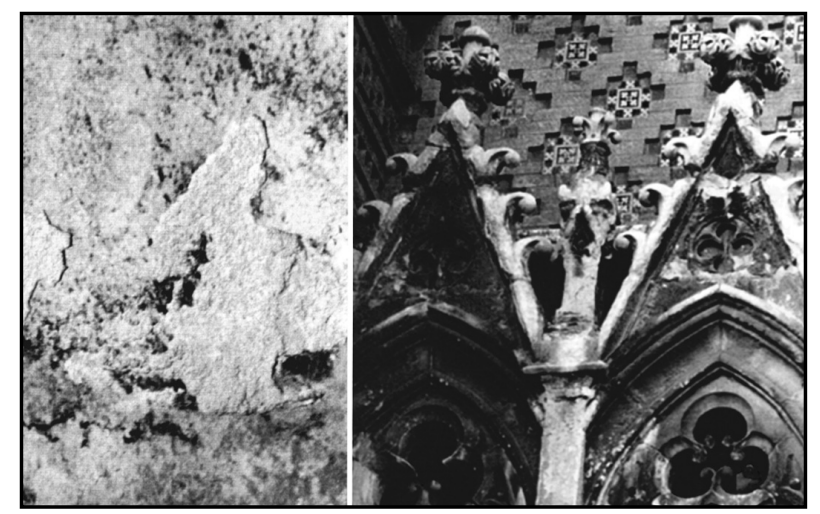

Figura 5. Detalle del estado de conservación: pátina y piedra subyacente (izquierda) y pináculos de galería baja de la fachada principal (derecha).

Figure 5. Detail of the state of conservation: patina and underlying stone (left) and lower gallery pinnacles on the main façade (right).

Al estudiar las muestras al microscopio óptico petrográfico, se pudo observar que entre piedra y pátina existía una estrecha banda con textura microcristalina diferenciada (Figura 6). Esto se debe a la redisolución de la piedra y de las sales almacenadas, y su posterior recristalización bajo la pátina; al tener ésta, escasa permeabilidad. Las presiones en los procesos de cristalización de las sales han provocado por tanto, en diferentes áreas, la formación de ampollas y desplacaciones, con el correspondiente desprendimiento de la pátina.
When the samples were studied under a petrographic optical microscope, a narrow band with a differentiated microcrystalline structure was observed between stone and coating (Figure 6). This was due to redissolution of the stone and accumulated salts and their subsequent recrystallization underneath the scantly permeable coating. Consequently, the pressure arising during salt crystallization generated blistering and flaking in different areas, with the concomitant detachment of the coating. 
Con relación a la costra negra, indicar que está concentrada en las zonas de retención de humedad sin acción de lavado. A lo largo del tiempo, se ha ido formando sobre pátina y sobre piedra; en este último caso, debido a los procesos de pérdida de esta capa de protección. Sobre la pátina, tiene gran adherencia, poco grosor y escasa rugosidad. Cuando se ha desarrollado directamente sobre el material pétreo, suele ser de tipo dendrítico y acostumbra a estar separada del sustrato ya arenizado. Su análisis mediante SEM-XEDS, y su mapa de elementos, muestra
Black crust concentrated in areas retaining moisture but not washed by rain. Over time, it has grown on coating and stone due, in the latter case, to the detachment of the protective layer. The crust forming on the coating was found to be tightly bonded, thin and fairly smooth. When it formed directly on the stone, it was generally dendritic and separated from the disaggregated substrate. SEM-EDX analysis and the element map exhibited the usual hydrocarbon and crystalline salt residues, the latter primarily calcium and magnesium sulphate. The crust

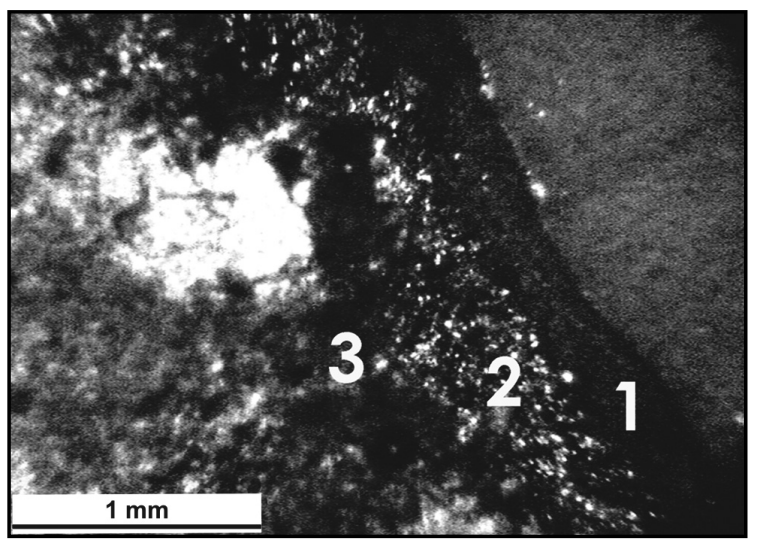

Figura 6. Imagen a microscopio óptico petrográfico nicoles cruzados: pátina (1), área de redisolución (2) y piedra (3).

Figure 6. Petrographical optical microscope image crossed polar: patina (1), re-dissolution area (2) and stone (3).

los habituales residuos de hidrocarburos y sales cristalinas tipo sulfatos, mayoritariamente de calcio y magnesio. Los grosores de la costra más habituales oscilan entre 100 y $200 \mu \mathrm{m}$, existiendo, en algunos puntos, grosores de 300 $\mu \mathrm{m}$. Lógicamente, el componente carbonatado de la roca ha favorecido este proceso de sulfatación intenso.

En el estudio de las sales, se realizaron tres campañas con apósitos de celulosa sobre el mismo punto, en piedra con y $\sin$ pátina, de $100 \mathrm{~cm}^{2}$. Se dejaron actuar 24 horas cubiertos con film de polietileno. Las mediciones obtenidas, además de confirmar que las sales eran abundantes, mostraron un comportamiento diferente en cada zona de análisis.

En los situados sobre piedra sin pátina, el apósito presentaba cierta humedad y ligera adherencia con el material en el momento de su retirada. Los valores de conductividad fueron de 834,652 y $612 \mu \mathrm{s} \cdot \mathrm{cm}^{-1}$. Estos resultados muestran que existe una dificultad en la eliminación de las sales debido a la penetración en la textura porosa del material; así como, el mal secado que, del aporte de agua, tiene la piedra.

En los colocados sobre piedra con pátina, el apósito estaba seco en el momento de su recogida. Las medidas fueron de 356, 349 y $350 \mu \mathrm{s} \cdot \mathrm{cm}^{-1}$. Esta similitud, apunta al was normally from 100 to $200 \mu \mathrm{m}$ thick, and up to 300 $\mu \mathrm{m}$ in some points. The carbonate component of the rock logically favoured this intense sulphation process.

For the salt study, three cellulose poultices were successively applied to $100 \mathrm{~cm}^{2}$ sample points, on coated and uncoated stone. They were held in place for 24 hours under a polyethylene film. The measurements obtained, in addition to confirming the existence of an abundance of salt, revealed differential behaviour in each area analyzed.

When placed on unprotected stone, the poultices were found to be somewhat moist and slightly bonded to the material when removed. The conductivity values were 834,652 and $612 \mu \mathrm{s} \cdot \mathrm{cm}^{-1}$. These results showed that salt penetration into the porous texture of the material, in conjunction with the scant drying capacity that characterizes the stone, constituted a hindrance to the elimination of the salts.

The poultices placed on coated stone were dry when removed. The measurements were 356, 349 and 350 $\mu \mathrm{s} \cdot \mathrm{cm}^{-1}$. This similarity is a further indication of the water 
carácter hidrófugo de esta capa que impide la acción de lixiviado que hace el apósito y, también indica que, al ser sus valores más bajos que sobre la piedra, la han protegido de la acción salina hacia el interior.

Por cromatrografía tipo HPLC, las principales sales solubles detectadas son los sulfatos (125,38 ppm), mientras que los nitratos son bajos (17,43 ppm), los nitritos inexistentes, y la concentración de cloruros es baja (6,22 ppm). Por tanto, la principal fuente de sales es el sulfato con origen, entre otros, en la contaminación ambiental.

De este modo, la predisposición o tendencia a la alteración por factores de origen diagenético del material pétreo, que genera la formación de abundante porosidad móldica intracristalina (Figura 7) y la consiguiente disgregación y arenización, se ve acelerada por la presencia de yeso extrínseco a la roca y con origen ambiental. repellence of this layer, which prevented the leaching action of the poultice, while the lower values found here than for the bare stone showed that the coating protected the stone from salt uptake.

According to the HPLC findings, the main salts detected were sulphates (125.38 ppm), while nitrate content was low (17.43 ppm), nitrites non-existent and chloride concentration likewise low (6.22 ppm). Consequently, the main source of salt was the sulphate generated, among others, by pollution.

The stone's proneness or tendency to be altered as a result of factors of diagenetic origin, which induce the formation of substantial intracrystalline mould porosity (Figure 7) and concomitant granular disaggregation, was heightened by the presence of extrinsic gypsum of an environmental origin.

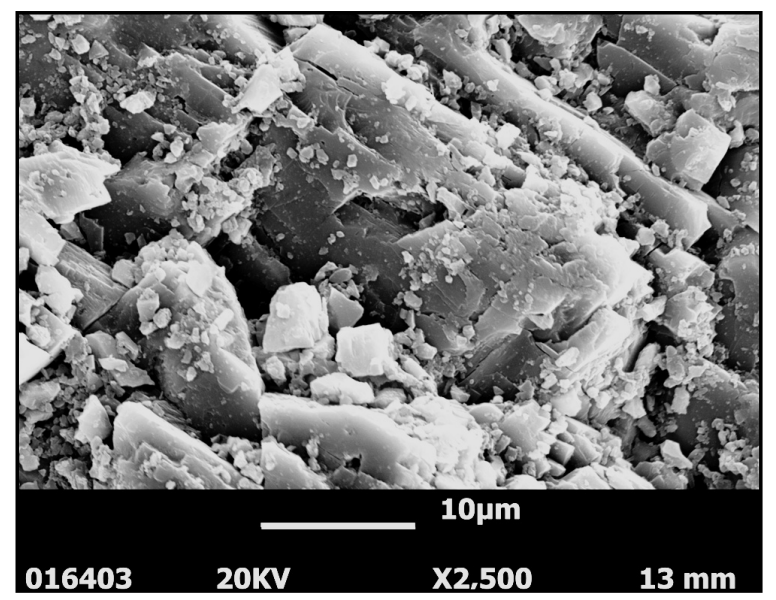

Figura 7. Cristales de dolomita con inicio de disolución del núcleo cristalino con déficit en magnesio.

Figure 7. Dolomite crystals, showing initial stages of dissolution of magnesium-deficient crystalline nuclei.

La pátina, a pesar de ser empleada como elemento protector de la piedra, acaba favoreciendo el deterioro, ya que ha reducido la permeabilidad del material pétreo de manera importante, formando una barrera que retiene el afloramiento de las sales solubles hacia el exterior que, por presiones de cristalización, acaban produciendo la desplacación de la pátina, y dejando un material alterado y arenizado.

En una fotografía de la década de 1950, procedente del Arxiu Fotogràfic de l'Institut Ametller d'Art Hispànic, se pudo apreciar que estos deterioros ya tenían origen antiguo. En la imagen, ya aparecen costras negras, pérdidas de material pétreo y de su pátina, desplacaciones, etc.; por lo que, su origen primero está asociado al medio ambiente anterior a esta fecha y, las características intrínsecas de la roca y pátina, y su interrelación, juegan un papel secundario, aunque importante.
Despite the fact that it was used to protect the stone, the coating ultimately favoured deterioration by substantially reducing stone permeability, forming a barrier that retains outward soluble salt efflorescence. The crystallization pressures generated by such salts caused the coating to flake, contributing to disaggregation of the material below.

A nineteen fifties photograph from the Arxiu Fotogràfic de l'Institut Ametller d'Art Hispànic (Ametller Institute of Hispanic Art, Photographic Archives) showed that this deterioration is not new. Indeed, the photograph reveals black crust, along with dimension loss of stone and coating, flaking and so on. Therefore, the origin can be attributed to the environmental conditions prevailing prior to that date, with the intrinsic characteristics of rock and coating and their inter-relationships playing a secondary albeit important role. 
Por tanto, la limpieza se hará sobre unas aportaciones de contaminantes y sales de las primeras décadas del siglo $X X$, que el modelo actual de contaminación de la ciudad no genera, pero que siguen actuando debido a la humedad y al agua pluvial.

\subsection{Ensayos de limpieza}

Sobre muestras extraídas de fragmentos de piezas que se iban a sustituir durante la obra, se procedió a realizar las pruebas de limpieza con proyección de abrasivos y láser; en piedra sin pátina y con pátina, que presentaba costra negra y depósitos de suciedad. En la piedra con pátina se ensayó en fragmentos que conservaban grosores de entre $170 \mu \mathrm{m}$ y de $500 \mu \mathrm{m}$.

Con relación al empleo de los abrasivos, y según datos de pruebas anteriores en diferentes materiales (12), se partió del empleo de vidrio micronizado y de silicato de aluminio por sus morfologías angulosas y sus durezas no muy elevadas de 6-7 Mohs, que los hacían apropiados para esta aplicación. Otros abrasivos posibles como el óxido de aluminio se descartaron por su dureza de 9 Mohs; las microesferas de vidrio por su forma, que implicaba una acción de impacto en la eliminación de la suciedad y que favorecería, en este caso, la eliminación de la pátina; y la piedra pómez, por la dificultad de eliminar los restos de polvo que quedarían en un material tan poroso como éste, a pesar de ser un abrasivo con una dureza baja de 5 Mohs.

Por tanto, los dos productos, químicamente neutros, que se usaron en los ensayos fueron:

- el silicato de aluminio (tamaños 80-160 $\mu \mathrm{m}$ y 100-300 $\mu \mathrm{m})$, producto granulado procedente de cámara de combustión, lavado, secado y clasificado, de color marrónnegro, exento de polvo, y con formas de grano irregulares, angulosas y ligeramente laminares.

- el vidrio granulado (tamaño 100-250 $\mu \mathrm{m}$ ), producto producido de la trituración de vidrio sodo-cálcico de clase neutra, de color blanco con formas irregulares ligeramente cúbicas y angulosas.

Para la proyección de ambos productos se utilizó una pistola de succión con boquilla recta de $6 \mathrm{~mm}$ de diámetro (Kit Pistola M-500), dejando una distancia, entre boquilla y muestra, de $10 \mathrm{~cm}$, realizando la proyección con un ángulo de entre $30-45^{\circ}$, para conseguir un efecto más suave de las partículas y eliminar la acción de impacto que podría tener un ángulo mayor. El tamaño de las catas fue de $100 \mathrm{~cm}^{2}$, cubriendo una pequeña zona sobre la que no se quería incidir en la limpieza para realizar la comparativa, con cinta adhesiva de papel. Se efectuaron diferentes pruebas, a presiones de 0,5, 1 y 1,5 bar, para ver cómo
Consequently, cleaning involved dealing with a type of pollution and salt from the early twentieth century no longer generated by the present model of urban pollution, but whose action is ongoing in the presence of moisture and rain water.

\subsection{Cleaning trials}

Abrasive blasting and laser cleaning trials were conducted on soiled stone fragments, with and without coating, taken from the pieces that were to be replaced during the works. On the fragments of stone where it existed, the coating was from 170 to $500 \mu \mathrm{m}$ thick.

Drawing from data from prior trials on several types of material (12), the abrasives initially used were micronized glass and aluminium silicate, whose angular morphology and moderate hardness (6-7 Mohs) made them appropriate for this purpose. Other possible abrasives were ruled out: aluminium oxide for its 9-Mohs hardness; glass microspheres, because due to their shape they would have to impact on the stone surface to eliminate the dirt and that, in this case, would damage the coating; and pumice stone, despite its low hardness (5 Mohs), for the difficulty involved in eliminating its powdery residue from such a porous material as limestone.

As a result, the chemically neutral products used in the trials were:

- 80-160 $\mu \mathrm{m}$ and 100-300 $\mu \mathrm{m}$ aluminium silicate, a brownish-black, dust-free, granulated, washed, dried and classified combustion chamber product with irregularly shaped, angular and slightly laminated particles.

- granulated glass (100-250 $\mu \mathrm{m})$, whose irregular, vaguely cubic, angular particles are the result of grinding neutral white calcium-sodium glass.

Both products were blasted onto the samples with a blasting gun with a straight, $6 \mathrm{~mm}$ diameter nozzle (Kit Pistola M-500). The distance between nozzle and sample was $10 \mathrm{~cm}$ and the gun was held at an angle of from 30 to $45^{\circ}$ to mitigate particle impact. Paper-based adhesive tape was used to cover a small area of the $100 \mathrm{~cm}^{2} \mathrm{spe}-$ cimens that was not to be cleaned for purposes of comparison. Several tests were conducted, at pressures of 
podía afectar el aumento de presión, manteniendo el resto de parámetros constantes.

Con relación al láser, para la realización de las pruebas de limpieza, se utilizó el equipo Maestro, Q-switched Nd:YAG bombeado por diodos, con una longitud de onda de 1064 $\mathrm{nm}$, que emite pulsos de 10 nanosegundos con una frecuencia de repetición de $10-200 \mathrm{~Hz}$ y con una energía por pulso regulable de 2-12 mJ. La distancia media de trabajo, entre la superficie a limpiar y la salida de haz, ha sido de $3,8 \mathrm{~cm}$ de distancia, al tratarse de un equipo con focalización del haz a esa distancia. Esto suponía un diámetro de spot sobre la costra de $1 \mathrm{~mm}$, siendo por tanto, la superficie irradiada de $0,79 \mathrm{~mm}^{2}$.

Se realizaron diferentes ensayos de $4 \mathrm{~cm}^{2}$, variando la energía y la frecuencia de repetición, hasta conseguir una limpieza idónea, tanto sobre costra seca como humedecida mediante vaporización de agua desionizada (13). Al hablar de limpieza idónea, no sólo se tuvo en cuenta no afectar a los materiales; sino que también, pudiera ofrecer una velocidad de trabajo aceptable en caso de que se decidiese su utilización; por lo que los ensayos se centraron en energías por pulso de entre 9 y $12 \mathrm{~mJ}$ y frecuencias de entre 100-200 Hz. En la mayoría de los casos, tanto en la aplicación en seco como en húmedo, y dependiendo del grosor de la costra, fue necesario hacer dos o tres aplicaciones con el láser sobre la superficie de la costra hasta su total eliminación.

\section{RESULTADOS}

De los diferentes métodos de limpieza que se pueden utilizar en obras de restauración (14), y con los datos obtenidos durante el estudio de la piedra, de su pátina y de sus alteraciones, se desecharon las limpiezas mediante agua o mediante producto químico en forma de apósito.

La limpieza con agua, ya fuese nebulizada o vaporizada, se descartó por:

- la incapacidad de esos sistemas para disolver los grosores de costras presentes en el edificio.

- la composición de la roca, con una fábrica cristalina de dolomitas muy alterable por el agua.

- la porosidad atrapante del material pétreo, que facilita la retención de agua y de humedad.

- el elevado volumen de sales, ya que se produciría una removilización importante de las mismas durante el proceso de limpieza.

Las limpiezas con aplicación de apósito de carbonato de amonio o AB-57, que acostumbran a ser efectivas para estos casos, se descartaron por:
$0.5,1$ and 1.5 bar to determine the effect of increasing the pressure when all other parameters were constant.

For the laser cleaning trials, in turn, the equipment used consisted in a diode-powered Maestro Q-switched Nd:YAG laser with a wavelength of $1064 \mathrm{~nm}$, a 10 nanosecond pulse width at frequencies of $10-200 \mathrm{~Hz}$ and adjustable delivered energy per pulse of from 2-12 $\mathrm{mJ}$. The mean working distance between the surface to be cleaned and the beam source was $3.8 \mathrm{~cm}$, the beam focal distance for this apparatus. The spot diameter under these conditions was $1 \mathrm{~mm}$, for an irradiated surface of $0.79 \mathrm{~mm}^{2}$.

Trials were conducted on $4 \mathrm{~cm}^{2}$ patches on both dry and de-ionized water vapour-moistened crust, varying the delivered energy and frequency until ideal cleaning was attained (13). Ideal cleaning was defined to mean not only having no effect on the material, but also an acceptable working speed in the event of actual use. Consequently, the delivered energy per pulse used for the trials ranged from 9 to $12 \mathrm{~mJ}$ at frequencies of from 100 to $200 \mathrm{~Hz}$. In most of the dry and moist trials, depending on thickness, the crust had to be beamed two or three times with the laser to attain complete removal.

\section{RESULTS}

Of the various cleaning methods available for restoration work (14), water-based or chemical poultices were ruled out on the grounds of the data collected during preliminary studies of the stone and its coating and alterations.

Cleaning with water, in spray form or nebulized, was disregarded for the following reasons:

- the incapacity of such systems to dissolve crusts of the thickness found on the building.

- stone composition, for its dolomite crystalline grain fabric, easily altered by water.

- the closed porosity of the stone, which favours water and moisture retention.

- the high salt volume, for the cleaning process would entail substantial remobilization of the salts.

Cleaning with ammonium carbonate or $A B-57$ poultices, often found to be effective in these cases, was disregarded for the following reasons: 
- la red porosa de esta caliza, al ser muy difícil determinar la neutralización de los tratamientos y el residuo que pudiese quedar en la porosidad atrapante del material.

- el emblanquecimiento general de la superficie donde se conserva la pátina, que resulta muy difícil de eliminar tras la aplicación estos productos $(15,16)$.

- el volumen de agua que se utilizaría durante todo este proceso, con las desventajas señaladas al valorar las limpiezas con agua.

Estas premisas permitieron plantear la realización de los ensayos con proyección de abrasivos y láser.

En las muestras de proyección de abrasivos sobre piedra sin pátina, tras las primeras valoraciones mediante lupa estereoscópica, se descartaron las realizadas con silicato de aluminio, para este caso concreto. La granulometría 80$160 \mu \mathrm{m}$ no conseguía una limpieza del área tratada, dejando restos de suciedad y de costra; y si se insistía para eliminarlos, se producía erosión de la superficie. El tamaño 100-300 $\mu \mathrm{m}$ presentaba una problemática similar. En cambio, el vidrio granulado de 100-250 $\mu \mathrm{m}$ mostraba un grado de limpieza aceptable y uniforme. Con relación a la presión, se observaba claramente que un aumento ligero de la presión aumentaba el daño sobre este material.

Por tanto, en las catas de limpieza sobre piedra sin pátina (Figura 8), se evidenció que la limpieza con vidrio micronizado a una presión de 0,5 bar, resultaba adecuada sin provocar daño a la superficie ni modificación superficial de la misma; mientras que las presiones superiores ensayadas, sí modificaban la textura del material y aumentaban la rugosidad. La información obtenida mediante SEM-XEDS y el mapa de elementos confirmó estos datos visuales.

En las muestras sobre piedra con pátina, se observó que los resultados de la limpieza eran similares a los de la piedra sin pátina. Las granulometrías empleadas del silicato
- the pore network of this limestone, which makes treatment neutralization difficult to determine and might trap the residue in the closed pores.

- the general whitening of the coated surface, which is extremely difficult to remove after these products are applied $(15,16)$.

- the volume of water used during this process, in light of the drawbacks to water-based cleaning listed above.

In view of the foregoing, the study focused on abrasive blasting and laser methods.

After the first stereomicroscope assessment of the abrasive-blasted bare stone samples, the aluminium silicate abrasive was ruled out for this specific case. Cleaning with this product was incomplete, for traces of black crust and dirt remained after application of the 80-160 $\mu \mathrm{m}$ grain size product, and further applications damaged the surface of the stone. Similar problems were encountered when the 100-300 $\mu \mathrm{m}$ abrasive was used. In contrast, cleaning with 100-250 $\mu \mathrm{m}$ granulated glass was acceptable and uniform, although raising the pressure, no matter how slightly, increased the damage caused to the material.

Consequently, in the bare stone samples (Figure 8), a pressure of 0.5 bar proved to sufficient to clean the surface without damaging or altering the stone, whereas the higher pressures tested modified the texture and increased the roughness of the material. The SEM-EXD information and element map confirmed these visual data.

The results for the coated samples were similar to the findings for the bare stone specimens. The silicate abrasive, at the grain size used, failed to clean the surface tho-

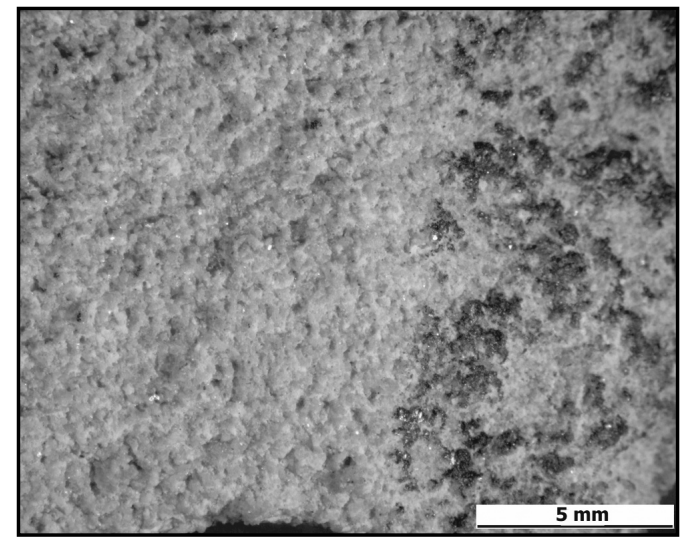

Figura 8. Detalle de limpieza con abrasivo de piedra sin pátina.

Figure 8. Details of stone after abrasive cleaning without patina. 
no acaban de limpiar la zona tratada; y si se insistía se producía daño a la superficie de la pátina, patente por la perforación de la misma en zonas puntuales. En cambio, el vidrio granulado, tanto en las muestras con grosor de patina sobre $170 \mu \mathrm{m}$ como en las de $500 \mu \mathrm{m}$ resultaba apropiado a una presión de 0,5 bar; aumentos ligeros de presión también la afectaban.

Por tanto, la forma aristada y ligeramente cúbica del vidrio granulado que, con los parámetros indicados, actúa por roce y deslizamiento, y con impacto prácticamente nulo dio, en este caso, mejor resultado que la forma aristada laminar del silicato de aluminio. Además, al ser su granulometría muy ajustada, presentaba la ventaja de efectuar una acción homogénea sobre la superficie.

Hay que señalar que, tanto en los fragmentos con pátina de 170 um como en los de 500 mm, la limpieza producía un muy ligero rebaje de la pátina, siendo necesario, no superar la presión apuntada y mantener el resto de los parámetros. También se comprobó que, donde la pátina tenía un mayor grosor y su aspecto visual era más cristalino, a pesar de mantenerse, se producía un leve matizado de la superficie, modificando ligeramente su textura cristalina.

En los ensayos de limpieza con láser, los parámetros, de entre las diferentes opciones que se utilizaron $y$, con los que se obtuvo una cierta rapidez en la limpieza, fueron los realizados con una energía de $10 \mathrm{~mJ}$ y una frecuencia de $150 \mathrm{~Hz}$, en los que dicho equipo acostumbra a estar optimizado (17), siendo la superficie irradiada de $0,79 \mathrm{~mm}^{2}$ y trabajando, por tanto, con una fluencia de $1,26 \mathrm{~J} / \mathrm{cm}^{2}$. Con estos parámetros, se pudo comprobar también, que la limpieza y la ablación eran más eficientes en las catas realizadas sobre superficie previamente humedecida con agua, que en las que la costra estaba seca. Aun así, el proceso continuaba siendo lento para su aplicación en obra.

En la imagen SEM de retrodispersados (Figura 9) en la que aparecen también los elementos principales de la pátina original de un fragmento que presentaba grosor de unas $170 \mu \mathrm{m}$, se puede apreciar como en la muestra tratada con abrasivos, a pesar de mantenerse la pátina, se empiezan a entrever los componentes de la piedra; mientras que en la tratada con láser, la pátina se mantiene con mayor grosor, al no detectarse la textura granular de la roca. Asimismo se puede observar cómo la textura superficial de la pátina con la limpieza láser es mucho más uniforme que la realizada con vidrio granulado, que la deja algo más rugosa y con ligeros impactos en la superficie.

La observación a microscopio óptico láser confocal (Figura 10), confirmó lo observado mediante SEM-XEDS. Tras la limpieza, tanto con proyección de vidrio micronizado como con láser, la pátina se mantenía ya que, la fluorescencia del sustrato calcáreo contrastada con la no- roughly and re-application damaged and even perforated the coating. The granulated glass at a pressure of 0.5 bar, however, sufficed to clean both the $170 \mu \mathrm{m}$ and the $500 \mu \mathrm{m}$ coatings, although slight increases in pressure caused surface alterations.

Therefore, the angled and vaguely cubic shape of the granulated glass which, at the parameters specified above, rubbed and slid against the stone surface with practically no impact, proved to be more effective in this case than the laminated angularity of the aluminium silicate. Moreover, the narrow range of grain size ensured uniform action.

It should be noted that that on the coated fragments, regardless of the thickness, cleaning thinned the cover slightly. As a result, the pressure could not be raised and all the other parameters indicated had to be strictly observed. In addition, while the thicker and visually most crystalline coating was found to remain intact, its surface shine was slightly dimmed due to minor alteration of the crystalline texture.

Various combinations of variables were tested in the laser cleaning trials, with cleaning found to be speediest when the delivered energy was $10 \mathrm{~mJ}$ and the frequency 150 $\mathrm{Hz}$, settings at which the apparatus used is generally optimized (17). With a beamed area of $0.79 \mathrm{~mm}^{2}$, the energy density was $1.26 \mathrm{~J} / \mathrm{cm}^{2}$. At these parameters, cleaning and ablation were found to be more efficient in the watermoistened samples than the dry crust. Even so, however, the process was too slow for practical on site use.

The backscattered SEM image (Figure 9), in which the main elements of the original coating in a $170 \mu \mathrm{m}$ thick fragment are visible, shows that while the coating was maintained in the abraded sample, the components of the stone were partially discernible. In contrast, in the laser-treated sample, the coating was thicker, for the granular texture of the stone could not be detected. At the same time, the surface texture of the laser-cleaned coating was much smoother than the surface cleaned with granulated glass, which was faintly roughened and bore slight impact scars.

Observation under a confocal laser microscope (Figure 10) confirmed the SEM-XEDS findings. After both micronized glass blasting and laser cleaning, the coating remained intact, for the visible contrast between the fluorescence of the calcareous substrate and the non-fluores- 


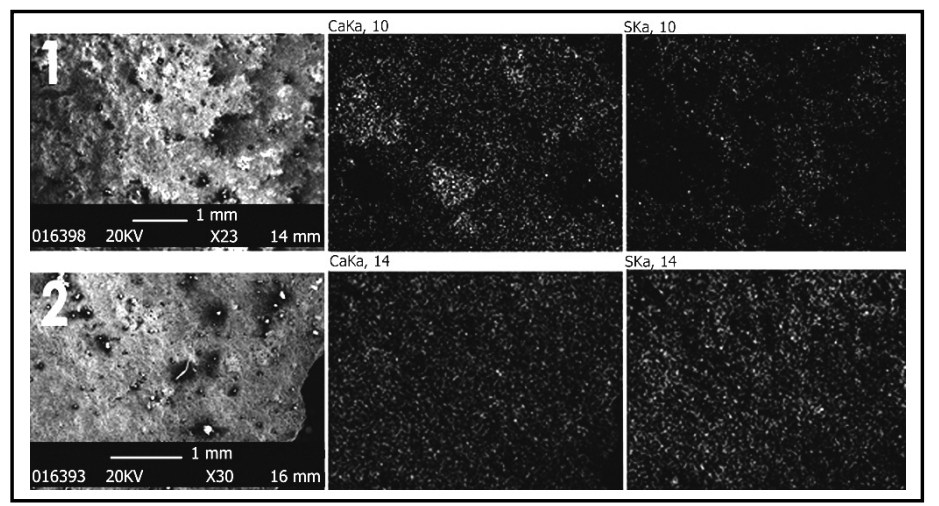

Figura 9. Elementos principales de la pátina tras la limpieza con abrasivos (1) y láser (2).

Figure 9. Element map of the coating after abrasive (1) and laser (2) cleaning.

fluorescencia del yeso de la pátina, indica que ésta no se ha eliminado.

Por tanto, se pudo determinar que la técnica mecánica de proyección de abrasivo a baja presión, con vidrio micronizado de 100-250 $\mu \mathrm{m}$, y la limpieza láser, resultaban válidas para la realización del trabajo, evitando los problemas y las desventajas que, por las características de la piedra y de su pátina, suponía el empleo del agua. cence of the gypsum in the coating indicated that the latter had not been eliminated.

Consequently, both low pressure abrasive blasting with 100-250 $\mu \mathrm{m}$ micronized glass and laser cleaning were found to be effective and free of the problems and drawbacks encountered when washing this stone with water, whose use cannot be recommended in light of the properties of the stone and the characteristics of its coating.

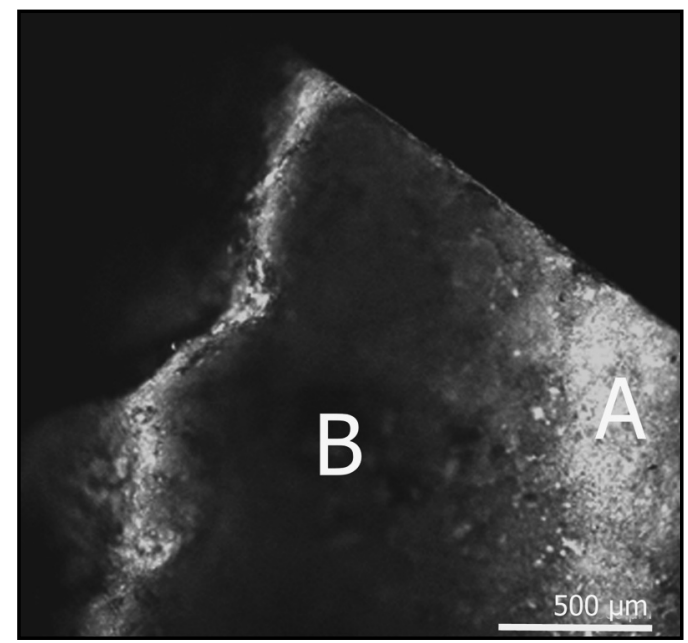

Figura 10. Imagen en láser confocal mostrando el contraste entre la fluorescencia del sustrato calcáreo de la piedra (A) y la no-fluorescencia de la pátina de yeso (B) tras limpieza con abrasivo.

Figure 10. Confocal laser image showing contrast between the fluorescence of the calcareous stone substrate $(A)$ and non-fluorescence of the gypsum coating (B) after abrasive cleaning.

\section{DISCUSIÓN}

En muchas intervenciones en las que se precisa realizar una limpieza de materiales constructivos en trabajos de restauración, las características de los materiales y de sus alteraciones desaconsejan los métodos basados en agua, ya sea como agente de limpieza o de neutralización.

\section{DISCUSSION}

In restoration work that calls for cleaning, the characteristics of the construction materials involved and their alterations often rule out the use of water-based cleaning or neutralization methods. 
Para estos casos, el empleo de la técnica mecánica de proyección de abrasivos a baja presión puede ser efectiva si se controlan sus diferentes parámetros. A partir de los diferentes ensayos que se deben realizar con todas la variables que la técnica permite, se puede llegar a determinar el material abrasivo más apropiado y su granulometría. Variaciones en el producto y en su tamaño, en la presión, en el ángulo de proyección y en la distancia, permiten obtener diferentes grados de limpieza y diferentes resultados en las muestras tratadas, pudiendo determinar la actuación más apropiada.

Asimismo, la valoración de este tipo de limpiezas, en las que actúa una acción mecánica en la eliminación de las costras y de los depósitos superficiales de suciedad permite que, con métodos analíticos sencillos, se pueda disponer de la información necesaria para valorar los ensayos de limpieza realizados, en los casos en los que se precisa una respuesta rápida para no interferir en las etapas de trabajo de una obra de restauración.

La técnica de limpieza con láser, que tampoco implica el empleo de agua, a pesar de que acostumbra a presentar resultados más idóneos que otros métodos, tiene, actualmente un coste muy elevado para utilizarse en superficies grandes. Por el momento, hace que su aplicación generalizada resulte inviable. Por lo que, otros métodos de limpieza, como en este caso, la proyección de vidrio micronizado con los parámetros ensayados, pueden dar resultados aceptables.

\section{AGRADECIMIENTOS}

Los autores agradecen el apoyo recibido por el promotor de la obra, Institut Germans Maristes de Catalunya, y por la dirección facultativa, David Barrera (Arquitecto) y Jaume Teixidó (Arquitecto Técnico), así como por las facilidades prestadas por la empresa constructora Obras y Rehabilitaciones Gruman, SL. en todos los trabajos de extracción de muestras y visitas de obra. También agradecen la colaboración de la empresa Materias Primas Abrasivas, SL. por el suministro de los productos y equipos empleados en los ensayos de limpieza. Los autores también subrayan las aportaciones en el estudio del resto de colaboradores de CETEC-patrimoni.
In such cases, the use of low pressure abrasive blasting may be effective if the respective parameters are closely monitored. The most suitable abrasive material and grain size can be determined by conducting all the necessary trials and testing all the variables that existing techniques allow. The different degrees of cleaning and sample resistance to treatment found with the various products, grain size, pressure, blasting angle and distance combinations provide a basis for defining the most appropriate procedure.

Moreover, as this type of cleaning is based on mechanical action to eliminate crusts and surface dirt, simple analytical methods can be deployed to rapidly obtain any information required to assess the cleaning test results so as not to interfere in other stages of restoration work.

Laser cleaning techniques, which are likewise water-free, yield better results than other methods but are presently very costly, making generalized application currently unfeasible. For the time being, then, other methods, such as micronized glass blasting under the controlled conditions studied here, afford acceptable results.

\section{ACKNOWLEDGEMENTS}

The authors wish to thank the developer, Institut Germans Maristes de Catalaunya and site managers David Barrera (architect) and Jaume Teixidó (associate architect) for their support, as well as the builders, Obras y Rehabilitaciones Gruman, S.L., for the facilities provided during sample extraction work and site visits. They are likewise appreciative of the cooperation received from Materias Primas Abrasivas, S.L. for supplying the products and equipment used in the cleaning trials. They also stress that this study benefited from the contributions made by the rest of the CETEC-patrimoni staff.

\section{BIBLIOGRAFÍA / BIBLIOGRAPHY}

(1) AA.VV.: Catàleg del Patrimoni Arquitectònic Històrico-Artístic de la Ciutat de Barcelona, Ficha 740, Ajuntament de Barcelona (1987).

(2) Alcoy, R.: "La arquitectura religiosa de Joan Martorell y el eclectismo fin de siglo", D'Art, no 10 (1984), pp. 221-239.

(3) NORMAL 20/85. Interventi Conservativi: Progettazione, Esecuzione e Valutazione preventiva.

(4) NORMAL 3/80. Materiali Lapidei: Campionamento.

(5) Dickson, J. A. D.: "A modified staining techniques for carbonates in thin section". Nature, no 205 (1965), pp. 587.

(6) Gooddard, E. N., Trask, P. D., De Ford, R. K., Rove, O. N., Singewald, J. T., Overberk, R. M.: The Rock-Color Chart. Geological Society of America. (1980). 
(7) Folk, R. L.: "Practical petrographic classification of limestones", Bull. Am. Assoc, Petrol. Geol., no 43 (1959), pp 1-38.

(8) Folk, R. L.: Classification of Carbonate Rocks, Am. Assoc. Petrol. Geol. Mem. no 1 (1962), pp. 62-84.

(9) Tucker, M. E., Wright, V.P.: Carbonate Sedimentology, pp. 371-379, Blackwell Scientific Publications, London, (1990).

(10) Prada, J. L.: Caracterización de formas y procesos de alteración observados en piedra de construcción de edad miocénica del área monumental de Tarragona. Tesis Doctoral, Universidad de Barcelona, (1995).

(11) Prada, J. L., Valenciano, A., Navarro, A.: "Procesos de alteración de materiales pétreos en edificios de interés histórico". Acta Geológica Hispánica, Vol. 30, no 1-3 (1995-96), pp. 97-110.

(12) Iglesias, M.: "Un ensayo de limpieza de superficies delicadas por proyección de abrasivos a baja presión", AKOBE. Restauración y conservación de bienes culturales, no 4 (2003), pp. 13-16.

(13) Esbert, R. M., Grossi, C. M., Alonso, F. J., Ordaz, J. \& Rojo, A.: "Características de la piedra que permiten valorar los efectos de la limpieza láser" Conservación del Patrimonio: Evolución y Nuevas Perspectivas. Actas 1er Congreso GEIIC (2002), pp. 363-367.

(14) Lazzarini, L. y Laurenzi Tabasso, M.: Il restauro della pietra. CEDAM, Padova, (1986).

(15) Iglesias, M.: "Eliminación de la costra negra en relieves calcáreos del Pabellón de Quirófanos del Hospital de la Santa Creu i Sant Pau", VII Reunió Tècnica de Conservació i Restauració. Grup Tècnic (2000), pp. 181-189.

(16) Iglesias, M., Gea, B., Prada, J. L., Guasch, N.: "Low-pressure abrasive cleaning of historic building materials", Proceedings of the International Conference on Heritage, Weathering and Conservation (2006), pp. 681-686.

(17) Sáiz, B.: La limpieza de materiales pétreos con la técnica láser. Determinación de los parámetros de limpieza láser para una Gárgola de las Torres de Serranos de Valencia. Tesis Doctoral, Universidad Politécnica de Valencia, (2003). 